\title{
Curriculum Ideology and Politics: Research on the Practice of Consumption Psychology Practice Curriculum Divided Classroom Teaching Practice
}

\author{
Wei Zhao ${ }^{1}$, Yunping $\mathbf{A i}^{\mathbf{2}^{*}}$ \\ ${ }^{1}$ He fei vocational college of finance and economics, Hefei230601,Anhui, China \\ ${ }^{2}$ School of International Business, AnhuiInternational Studies University, Hefei231201, Anhui, China \\ *Corresponding Author.
}

\begin{abstract}
At present, improving the practical effect of ideological and political courses has become a hot issue in many vocational colleges. The article cuts into the classroom teaching model, uses teaching experiments, questionnaire surveys, interviews and other research methods to design the integration of the ideological and political elements of the consumer psychology practice curriculum, the implementation of the teaching process, and the feedback of teaching results. The results show that: The dual classroom teaching model of information technology such as the media can better meet the learning characteristics and needs of students in higher vocational colleges and has a significant effect on improving the ideological and political teaching of consumer psychology practical courses. At the same time, we also hope to provide some ideas for reference to the ideological and political education of the same type of courses in other higher vocational colleges.
\end{abstract}

Keywords: Pad Class, Ideological and Political Theories teaching in All Course, Integrative teaching mode

\section{Introduction}

Colleges and universities are carrying the important task of "moral education". Ideological and political courses can fully tap the ideological and political resources of various courses, give play to the unique educational role of each course, realize the smooth integration of explicit and implicit education, and comprehensively improve the quality of personnel training ${ }^{[1]}$. Facing the complicated international situation, the contemporary college students have diversified values and abundant Internet information resources, and are immersed in the fragmented and personalized learning experience of various new media. The attraction and influence of some traditional teaching modes and methods are declining, which makes it difficult to meet the learning needs of students ${ }^{[2]}$. In many higher vocational colleges, the expected effects of curriculum ideology and politics are not satisfactory due to the characteristics of the source of students, teaching management and many other factors. It is particularly important to explore a teaching model suitable for the current academic conditions of our vocational students. The split classroom teaching mode put forward by Professor Zhang Xuexin of Fudan University plays an important role in better implementing student-centered, mobilizing students' initiative and effectively improving the effectiveness of ideological and political teaching in higher vocational professional courses.

So far, The existing research on split classroom and curriculum ideological and political education mainly focuses on the following three aspects: the first is the research on split classroom mode and curriculum ideological and political theory ${ }^{[3]}$. the second is the application research on split classroom and curriculum ideological and political education ${ }^{[4]}$. the third is the research on implementation path and teaching means ${ }^{[5]}$. However, there are few researches on the integration of separate classroom and ideological and political education. At present, there are only two papers on how to carry out ideological and political education on the Internet.Based on the existing literature research and curriculum practice, the main contributions of this paper are as follows: first, taking the integration of split classroom and curriculum ideological and political education in Higher Vocational Colleges as the research object, it makes up for the lack of domestic scholars' research in this field to a certain extent. Second, although the current research involves multi-disciplinary and multi-course, this paper takes the consumer psychology practice course as an

ISSN: 0010-8189

(C) CONVERTER 2021 
example to fill the gap in this course. The third study provides some new ideas for the integration of college teaching mode and ideological and political education in similar courses.

\section{The value and significance of the ideological and political implementation of the separate classroom in the practical course of consumer psychology}

Consumer psychology is a comprehensive course with equal emphasis on theory and application. It has the characteristics of many majors, large base of students and strong demand for personalized learning. At present, in many colleges and universities, in the classroom teaching of consumer psychology practice, teachers generally spend more time imparting knowledge.It reduces the time of preview before class and review after class, resulting in the lack of interaction in class and students' autonomous learning. Although some students actively participate, this mode can not attract other students with insufficient interest or weak foundation.Therefore, it not only makes the teaching effect unsatisfactory, but also makes the ideological and political function of the curriculum have little effect.

As a brand-new teaching mode, split classroom. Since its birth in 2014, many educators have carried out a lot of practical exploration and research in combination with their respective disciplines and fields, and achieved fruitful results. At the same time, it also proves that the separate classroom teaching mode is quite suitable for China's national conditions. The core of dividing the classroom is to change the traditional classroom teaching mode and divide the classroom flexibly into two parts.Some of them are given to the teachers to teach the framework and key points. The other part is given to the students to discuss the interactive learning on the basis of internalization and absorption. It mainly includes three links: the teaching of learning points, the internalization of knowledge, and the application of knowledge on the basis of discussion and exchange ${ }^{[6]}$. According to the actual teaching needs, the form of bisection can be divided into on-the-spot bisection and separated bisection. In terms of assessment methods, it pays attention to process evaluation and emphasizes stimulating students' autonomy and enthusiasm in learning. Pay attention to the interaction of different contents and levels between teachers and students, students and students, and fully mobilize the initiative of teachers and students. This is of great value and significance for the implementation of consumer psychology practice and the ideological and political education of similar professional courses.

\section{The Design and Implementation of the Dual Classroom in the Ideological and Political Courses of Consumer Psychology}

Based on the split classroom teaching mode, the ideological and political goals of the course are organically combined with the ability goals and quality goals of the course. Explore the ideological and political elements in the curriculum, and sort out and reconstruct the content of the curriculum, so as to make it more in line with the students' cognitive law. We should also focus on collecting and developing a series of teaching resources with students, such as new media resources, case manuals, question bank, which can meet the needs of students' autonomous learning and personalized learning. At the same time, timely feedback and evaluation of students' learning tasks will also make the curriculum arrangement more systematic and students easier to keep up with the pace of teachers.

3.1 Do a good job in the top-level ideological and political design of consumer psychology practice courses based on the bisection classroom teaching model

As an applied course, the teaching goal of consumer psychology practice is to analyze and solve practical problems in marketing activities from the perspective of psychology. Adopt corresponding psychological countermeasures of marketing activities, form marketing ideas and various skills, and apply them freely in marketing activities. At the same time, it enables students to have good communication and expression ability, innovative ability, courageous sense of social responsibility, good professional ethics and teamwork spirit. The ability and quality objectives in the teaching objectives of this course are highly consistent with the ideological and political objectives of the course, and the teaching tasks are matched with the exploration of Ideological and political elements in the course content. The

ISSN: 0010-8189

(C) CONVERTER 2021 
integration design of applied professional courses and ideological and political courses not only considers the common problems faced by the ideological and political courses, but also considers the personality of the students (as is shown in Table 1) ${ }^{[7]}$.

Table 1 Design and evaluation methods based on the integration of practical ideological and political elements of consumer psychology into the classroom

\begin{tabular}{|c|c|c|c|}
\hline $\begin{array}{l}\text { Course } \\
\text { content }\end{array}$ & $\begin{array}{l}\text { Curriculum ideological and } \\
\text { political integration point }\end{array}$ & $\begin{array}{l}\text { Halving classroom teaching } \\
\text { design }\end{array}$ & Evaluation method \\
\hline \multirow[b]{2}{*}{$\begin{array}{l}\text { Consumer } \\
\text { behavior } \\
\text { cognition }\end{array}$} & $\begin{array}{l}\text { The basic contents and principles } \\
\text { of consumer behavior research } \\
\text { are integrated into the world } \\
\text { vision and scientific methodology }\end{array}$ & $\begin{array}{l}\text { In class, the teacher focuses on } \\
\text { the content and basic principles } \\
\text { of consumer psychology research }\end{array}$ & $\begin{array}{l}\text { Test students' } \\
\text { Internalization effect with } \\
\text { the help of cloud class test } \\
\text { function }\end{array}$ \\
\hline & $\begin{array}{l}\text { "The development of consumer } \\
\text { psychology" incorporates the } \\
\text { pride of national development, } \\
\text { collectivism spirit and team } \\
\text { cooperation consciousness }\end{array}$ & $\begin{array}{l}\text { Divide the points in different } \\
\text { halls and discuss Alibaba case in } \\
\text { group form }\end{array}$ & $\begin{array}{l}\text { Multi-dimensional } \\
\text { evaluation of the group's } \\
\text { achievements and } \\
\text { participation in the form of } \\
\text { group mutual evaluation } \\
\text { and teacher evaluation }\end{array}$ \\
\hline \multirow{2}{*}{$\begin{array}{l}\text { Analysis of } \\
\text { Consumer } \\
\text { Psychologica } \\
1 \text { Activity } \\
\text { Process }\end{array}$} & $\begin{array}{l}\text { "Consumer's Psychological } \\
\text { Process of Understanding" is } \\
\text { integrated into "Five Identity } \\
\text { Education" and Family and } \\
\text { Country Feeling Education }\end{array}$ & $\begin{array}{l}\text { Divide in class, and the teacher } \\
\text { will give a intensive explanation } \\
\text { based on materials such as } \\
\text { "Wuhan Anti-epidemic" and } \\
\text { Xinjiang Cotton }\end{array}$ & $\begin{array}{l}\text { Detect students' } \\
\text { internalization effect with } \\
\text { the help of cloud class test } \\
\text { function }\end{array}$ \\
\hline & $\begin{array}{l}\text { "Consumer emotional process, } \\
\text { will process" into the four } \\
\text { consciousness, the dissemination } \\
\text { of value attributes of education }\end{array}$ & $\begin{array}{l}\text { Let students collect classic cases } \\
\text { of emotional marketing and } \\
\text { discuss them in brainstorming } \\
\text { section of class }\end{array}$ & $\begin{array}{l}\text { Student student mutual } \\
\text { evaluation under the } \\
\text { guidance of teachers with } \\
\text { the help of cloud class } \\
\text { brainstorming content }\end{array}$ \\
\hline \multirow[b]{2}{*}{$\begin{array}{l}\text { Analysis and } \\
\text { Application } \\
\quad \text { of } \\
\text { Consumers' } \\
\text { Personality } \\
\text { Self-concept }\end{array}$} & $\begin{array}{l}\text { "Consumer personality and } \\
\text { consumption behavior" is } \\
\text { integrated into professional ethics } \\
\text { and professional quality } \\
\text { education }\end{array}$ & $\begin{array}{l}\text { In class, the teacher focuses on } \\
\text { the study and judgment of } \\
\text { temperament and character }\end{array}$ & $\begin{array}{l}\text { Test students' } \\
\text { Internalization effect with } \\
\text { the help of cloud class test } \\
\text { function }\end{array}$ \\
\hline & $\begin{array}{l}\text { Personal self-concept is } \\
\text { integrated into correct values and } \\
\text { outlook on life }\end{array}$ & $\begin{array}{l}\text { The case of discussing Xiao } \\
\text { Wang's consumption behavior is } \\
\text { divided into classes to guide } \\
\text { students to analyze Xiao Wang's } \\
\text { consumption behavior according } \\
\text { to their actual life and then } \\
\text { understand consumers' } \\
\text { self-concept and consumption } \\
\text { behavior }\end{array}$ & $\begin{array}{l}\text { Multi-dimensional } \\
\text { evaluation of the group's } \\
\text { achievements and } \\
\text { participation in the form of } \\
\text { group mutual evaluation } \\
\text { and teacher evaluation }\end{array}$ \\
\hline \multirow{2}{*}{$\begin{array}{l}\text { Consumer } \\
\text { needs, } \\
\text { purchase } \\
\text { motivation } \\
\text { analysis, } \\
\text { purchase } \\
\text { decision } \\
\text { analysis }\end{array}$} & $\begin{array}{l}\text { "Consumer needs and } \\
\text { motivations" development } \\
\text { changes into the new } \\
\text { development concept }\end{array}$ & $\begin{array}{l}\text { Divide in class, and teachers will } \\
\text { teach knowledge through the } \\
\text { changes of "beautiful gifts" in } \\
\text { different eras }\end{array}$ & $\begin{array}{l}\text { Detect students' } \\
\text { internalization effect with } \\
\text { the help of cloud class test } \\
\text { function }\end{array}$ \\
\hline & $\begin{array}{l}\text { Training and cultivation of } \\
\text { "consumer purchase decision" } \\
\text { into thinking mode }\end{array}$ & $\begin{array}{l}\text { Through the experience of tea } \\
\text { auction process, students can } \\
\text { analyze and discuss the } \\
\text { influencing factors of consumers' } \\
\text { purchase decision }\end{array}$ & $\begin{array}{c}\text { In the form of group } \\
\text { mutual evaluation and } \\
\text { teacher evaluation, } \\
\text { multi-dimensional } \\
\text { evaluation of the group's } \\
\text { achievements and } \\
\text { participation was carried } \\
\text { out }\end{array}$ \\
\hline $\begin{array}{l}\text { Marketing } \\
\text { environment }\end{array}$ & $\begin{array}{l}\text { "Marketing Environment" is } \\
\text { integrated into Marxist "Five }\end{array}$ & $\begin{array}{l}\text { When the class is divided, the } \\
\text { teacher focuses on the macro }\end{array}$ & $\begin{array}{c}\text { Test students' } \\
\text { internalization effect with }\end{array}$ \\
\hline
\end{tabular}




\begin{tabular}{|c|c|c|c|}
\hline \multirow{2}{*}{$\begin{array}{l}\text { and } \\
\text { application } \\
\text { of consumer } \\
\text { psychology }\end{array}$} & Views" education. & $\begin{array}{l}\text { marketing environment and the } \\
\text { micro environment }\end{array}$ & $\begin{array}{l}\text { the help of cloud class test } \\
\text { function }\end{array}$ \\
\hline & $\begin{array}{l}\text { The integration of consumer } \\
\text { culture and consumer customs } \\
\text { into traditional Chinese culture, } \\
\text { emotional identity education }\end{array}$ & $\begin{array}{l}\text { Divide in pairs in separate rooms } \\
\text { and mobilize each student to } \\
\text { collect and share a case about the } \\
\text { impact of social culture and } \\
\text { consumer customs on consumer } \\
\text { behavior. And share }\end{array}$ & $\begin{array}{l}\text { Use the brainstorming } \\
\text { content of the cloud class } \\
\text { to conduct student-student } \\
\text { mutual evaluation under } \\
\text { the guidance of teachers }\end{array}$ \\
\hline \multirow{2}{*}{$\begin{array}{l}\text { Marketing } \\
\text { strategy and } \\
\text { consumer } \\
\text { behavior } \\
\text { application }\end{array}$} & $\begin{array}{l}\text { Integrating consumer products, } \\
\text { pricing, distribution and } \\
\text { promotion strategies into social } \\
\text { responsibility, rule of law and } \\
\text { public morality education }\end{array}$ & $\begin{array}{l}\text { In the classroom, teachers focus } \\
\text { on the marketing strategy } \\
\text { formulation based on consumer } \\
\text { psychology }\end{array}$ & $\begin{array}{l}\text { Test students' } \\
\text { Internalization effect with } \\
\text { the help of cloud class test } \\
\text { function }\end{array}$ \\
\hline & $\begin{array}{l}\text { Integrating "Consumer Marketing } \\
\text { Strategy Formulation" into } \\
\text { College Students' Innovation and } \\
\text { Entrepreneurship Education and } \\
\text { Cultivating Students' Innovation } \\
\text { Consciousness and Dedication }\end{array}$ & $\begin{array}{l}\text { Divided into classes, students } \\
\text { plan the project in team form and } \\
\text { put it into practice in combination } \\
\text { with the internet plus competition }\end{array}$ & $\begin{array}{l}\text { Teachers give priority to } \\
\text { process assessment and } \\
\text { result assessment }\end{array}$ \\
\hline
\end{tabular}

3.2 The Ideological and Political Implementation of Consumer Psychology Course Based on Dual Classroom

On the basis of the design and evaluation of the integration of Ideological and political education into the course of consumer psychology practice, we carry out the practical teaching of the course

3.2.1 Do a good job of learning situation analysis and timely teaching adjustment

Before the consumer psychology practice course was taught, a total of 512 students in the four majors and 10 classes were investigated. It was found that $89 \%$ of the students in the class spent 2-5 hours on mobile phones every day. $43 \%$ of students tend to use computers and mobile Internet for autonomous learning. $52 \%$ of students are satisfied with their previous class status. $69 \%$ of students who play mobile phones occasionally in class. $81 \%$ of students think that they lack hard work in their studies. However, in the survey of factors affecting classroom quality, $3 \%$ of students think that they are related to their interest in the course. $65 \%$ of the students think it is related to the teacher's curriculum content design. $3 \%$ of students think it has something to do with teaching management. $29 \%$ of students think it has something to do with their own quality. Through the above research results, it is not difficult to find that most students have a strong thirst for knowledge, but due to the weak ability of self-learning and self-discipline. Because of the difficulty of professional courses or the lack of enthusiasm for the major, it is difficult to maintain long-term attention and persistent learning state in the classroom. According to the characteristics of the students in the class, the materials that students are interested in are designed to enhance students' interest in autonomous learning, and the form of split class is adjusted in time according to the different learning situation.

3.2.2 Strengthen the integration of ideological and political course and reconstruct the course content

The teaching content is integrated on the basis of the integration design of learning goals and ideological and political education goals. "Consumer Psychology Practice" course is 11 items before content optimization. Through the reconstruction of the content, the content is optimized into 6 items. Each project extracts the main points of knowledge and self-made micro-classes, constantly supplements and updates the theoretical knowledge in the textbooks, and closely follows the current students' concerns, such as fighting the epidemic, the Sino-Indian border conflict in 2020, the Xinjiang cotton incident in 2021, and other hot issues. Course resources. Students are encouraged to make small scene simulation videos, collect synchronous cases, knowledge links, and the latest industry development trends, build a new media resource library for the course, and push it to the resource library of cloud class for sharing. In this way, the teaching hours of classroom theory are reduced, the students' autonomous learning is guided, the students' professional knowledge and cognitive ability are expanded, and the design of practical activities is increased. Then through various forms of discussion, it focuses on the application of consumer psychology in marketing and other professional ability and quality training.

ISSN: 0010-8189

(C) CONVERTER 2021 
3.2.3 Pay attention to the control of curriculum implementation and adopt multi-dimensional evaluation

Because it is difficult for vocational students to stay focused for a long time, teachers need to spend more time monitoring the present situation. In the teaching process, make full use of the information-based teaching environment created by the cloud classroom, guide students to study systematically through a series of tasks, and arouse students' enthusiasm. Before class, through cloud classroom+QQ group push, students are guided to build curriculum resource pool together, which promotes students' pre-class study and paves the way for classroom teaching. In the class, through the design of personalized tasks, students are guided to fully absorb and internalize the knowledge they have learned. Each activity is given corresponding experience value according to the difficulty, which improves students' enthusiasm for participation and stimulates students' fighting spirit. After class, we should arrange the tasks according to the students' needs, consolidate the students' absorption of the internalized results, and prepare for the discussion in separate classes.

In order to improve the effect of ideological and political teaching, in the course assessment of Consumer Psychological Practice, it is gradually implemented to focus on the quality of completing tasks, pay attention to the process assessment and innovate the result assessment. The usual assessment pays special attention to learning attitude, classroom discipline, team cooperation ability and so on. In view of the semester offered by consumer psychology practice and the supporting practice assessment of related courses, the evaluation is carried out in the form of entries of the "internet plus Innovation and Entrepreneurship Competition for College Students" held every year at different levels, from different angles and in all directions. The main body of evaluation adopts a multi-dimensional model of combined evaluation of teachers, students, and groups according to the actual situation. The details are shown in Table 2.

Table 2 Assessment content, assessment method and proportion

\begin{tabular}{|c|c|c|c|c|}
\hline Assessment type & Assessment content & $\begin{array}{l}\text { Evaluation } \\
\text { subject }\end{array}$ & $\begin{array}{l}\text { Assessment } \\
\text { form }\end{array}$ & $\begin{array}{l}\text { Proportion of total } \\
\text { score }\end{array}$ \\
\hline \multirow[b]{2}{*}{ Usual assessment } & $\begin{array}{c}\text { Quality of tasks completed in } \\
\text { each class }\end{array}$ & $\begin{array}{l}\text { Teachers and } \\
\text { students }\end{array}$ & $\begin{array}{c}\text { Task } \\
\text { assessment }\end{array}$ & \multirow[b]{2}{*}{$30 \%$} \\
\hline & $\begin{array}{l}\text { Classroom performance such as } \\
\text { attendance rate, learning } \\
\text { attitude, and learning discipline }\end{array}$ & Teacher & Behavior & \\
\hline \multirow{5}{*}{ Stage assessment } & $\begin{array}{l}\text { Assessment } 1 \text { consumer } \\
\text { behavior cognition }\end{array}$ & \multirow{5}{*}{ Teacher } & $\begin{array}{l}\text { Theoretical } \\
\text { questions }\end{array}$ & \multirow{5}{*}{$20 \%$} \\
\hline & $\begin{array}{l}\text { Analysis on the process of } \\
\text { consumer psychological } \\
\text { activities in assessment } 2\end{array}$ & & \multirow{4}{*}{$\begin{array}{c}\text { Task } \\
\text { development }\end{array}$} & \\
\hline & $\begin{array}{l}\text { The analysis and application of } \\
\text { the self-concept of the } \\
\text { personality of the examine } 3 \\
\text { consumer }\end{array}$ & & & \\
\hline & $\begin{array}{l}\text { Assessment } 4 \text { consumer needs, } \\
\text { purchase motivation analysis, } \\
\text { purchase decision analysis }\end{array}$ & & & \\
\hline & $\begin{array}{l}\text { The application of customer } \\
\text { relationship management in } \\
\text { marketing environment and } \\
\text { consumer psychology }\end{array}$ & & & \\
\hline $\begin{array}{l}\text { Practical } \\
\text { assessment }\end{array}$ & $\begin{array}{l}\text { Marketing strategy and } \\
\text { consumer behavior application }\end{array}$ & $\begin{array}{l}\text { Teachers, } \\
\text { students }\end{array}$ & $\begin{array}{c}\text { Project } \\
\text { assessment }\end{array}$ & $50 \%$ \\
\hline
\end{tabular}




\section{On the effect of Ideological and political education in the course of consumer psychology practice}

\subsection{Implementation effect verification}

4.1.1 Analysis of post test results

In this study, two parallel classes of marketing major were selected to carry out the experiment. One class carries out ideological and political teaching in traditional teaching mode, and the other class carries out ideological and political teaching based on split classroom mode. The teaching experiment consists of eight classes, and the questionnaire and test are completed by all the students who participate in the experiment after the eight classes. The main purpose is to test the learning effect and learning feeling of the students in the practical course of consumer psychology. After the experiment, we post-test the results and use SPSS23. 0 for statistical analysis. (See Table 3) The results show: the traditional classroom group's post-test score is 76.80 , and the split classroom group is 82.87 . Obviously the latter's score is higher than the former, and the two classes' course scores before the experiment are the average difference The score is 0.08 . In addition, the independent sample $\mathrm{T}$ test analysis of the two classes found that the two have significant differences $(\mathrm{P}=0.045<0.05)$, which shows that the dual classroom mode teaching mode has a significant effect on the curriculum ideological and political teaching.

Table 3 Comparison of performance between split class and traditional class

\begin{tabular}{|c|c|c|c|c|c|c|}
\hline class & $\mathrm{N}$ & average & $\begin{array}{c}\text { standard } \\
\text { deviation }\end{array}$ & $\begin{array}{c}\text { Standard error } \\
\text { of mean }\end{array}$ & T value & significance \\
\cline { 1 - 5 } $\begin{array}{c}\text { Traditional } \\
\text { classroom group }\end{array}$ & 52 & 76.80 & 4.372 & 1.468 & -2.306 & \multirow{2}{*}{0.045} \\
\cline { 1 - 5 } Split class group & 49 & 82.87 & 2.606 & 0.951 & \\
\hline
\end{tabular}

4.1.2 Learning experience analysis

The data in the following table (as shown in Table 3) shows how the students in the classroom group have increased their learning initiative and interest, "case group member participation", "knowledge response ability training", "teacher and student multi-dimensional interaction training". Items are significantly higher than the traditional model group. This reflects that the "split classroom" is indeed of great practical significance to teaching effectiveness. Through the investigation of the students' learning experience, it is found that the students in the sub class group recognize the attraction of integrating the current political hot teaching content, and think that they have significantly improved in "learning initiative and interest", "knowledge application ability" and "thinking innovation ability". There is little difference in "knowledge development ability" and "speech ability training".

Table 4. Practical results

\begin{tabular}{|c|c|c|}
\hline & Split class group & Traditional mode group \\
\hline $\begin{array}{c}\text { Job submission rate } \\
\text { Participation of case discussion } \\
\text { group members }\end{array}$ & $99 \%$ & $87 \%$ \\
\hline $\begin{array}{c}\text { Increased learning initiative and } \\
\text { interest }\end{array}$ & $100 \%$ & $56 \%$ \\
\hline Training of speech ability & $88 \%$ & $69 \%$ \\
\hline $\begin{array}{c}\text { Cultivation of knowledge } \\
\text { development ability }\end{array}$ & $72 \%$ & $61 \%$ \\
\hline $\begin{array}{c}\text { Cultivation of knowledge } \\
\text { application ability }\end{array}$ & $89 \%$ & $56 \%$ \\
\hline $\begin{array}{c}\text { Multi-dimensional interactive } \\
\text { training between teachers and } \\
\text { students }\end{array}$ & $76 \%$ & $79 \%$ \\
\hline $\begin{array}{c}\text { Cultivation of thinking } \\
\text { innovation ability }\end{array}$ & $89 \%$ & \\
\hline
\end{tabular}

4.1.3 Examination and analysis of innovative practice

ISSN: 0010-8189 
The instructor of this team uses various college student innovation and entrepreneurship competitions to conduct innovation practice assessment, and the student team completes the assessment task together in the form of project participation. Not only strengthened the cultivation of practical ability, but also discovered and incubated many entrepreneurial projects in the process. In July 2017, the Qingmang photography team won three awards in the "The 3rd Anhui Province Internet + College Students Innovation and Entrepreneurship Competition" in the Entrepreneurship Group, the Gold Award and the Best Employment Promotion Award. In August 2018, in the fourth Anhui Internet plus student innovation and entrepreneurship competition, the backpackers team won the gold medal of the entrepreneurial group. In 2019, the fifth Anhui province university student "Internet plus" university student innovation and entrepreneurship competition has scored seven silver awards. In the 10th "creativity, innovation, entrepreneurship" e-commerce challenge for college students in Anhui Province in 2020, the project directed by our team won one second prize (as is shown in Table 4).

\subsection{Teaching reflection}

Since the ideological and political teaching practice of this course based on the split classroom mode, the use of a variety of new media information teaching means is more in line with the learning needs and learning habits of today's higher vocational students. At the same time, using the cloud class test system to detect the internalized absorption of knowledge can not only let teachers know the absorption of students at the first time, but also give students timely feedback and encouragement, which can arouse students' enthusiasm for learning.

It is very important to control the teaching evaluation in the process of curriculum implementation, especially teachers should demonstrate by themselves in this process, and make sure that the evaluation standards are open and the evaluation links are fair and just. Because it not only plays a role of timely feedback and motivation, but also has an important impact on students' values and outlook on life in the process.

The teaching mode of "double classroom" actually puts forward high demands on teachers ${ }^{[8]}$. On the one hand, teachers not only need to systematically comb the teaching content based on the control of teaching materials, and do a good job of top-level design. On the other hand, teachers should continue to learn new media communication forms, enhance information technology means, enhance the attraction of teaching materials, at the same time, teachers should improve the control and adaptability of the whole teaching activities, and timely and effectively adjust according to the changes of learning situation.

\section{Conclusions}

Through the consumer psychology courses of the classes taught, the ideological and political practice based on the split classroom teaching mode is carried out. It is found that the bisection classroom model through the use of new media and other informational means is in line with the learning habits of today's vocational students. The active learning method that drives students to experience and explores can better meet the students' inherent growth needs and make the courses more attractive ${ }^{[9]}$. The internalization and discussion of the classroom is more conducive to arouse students' interest in learning. Especially, encouraging the group members to discuss and publicly express their opinions can not only cultivate students' ability of expression, communication ability, but also team awareness and team spirit. It has played a good role in improving the effect of Ideological and political teaching in Higher Vocational Colleges for a long time, and provides some reference for the construction and development of Ideological and political education in professional courses.

\section{Acknowledgements}

The formation mechanism and improvement strategy of online teaching quality based on effective teaching: [2020zdxsjg274]. 


\section{References}

[1] L.Y. Shi, "Thoughts on Constructing the Mechanism of Collaborative Education of Ideological and Political Education in College Courses," School Party Building and Ideological Education (Higher Education Edition), no. 10, pp. 41-43, 2018.

[2] B.M. Liu, Z.L. Jin, "Thoughts on Promoting Curriculum Ideological and Political Construction in Vocational Colleges," China Vocational and Technical Education, vol. 12, pp. 105-108, 2021.

[3] Q.H. Chen, W.K. Lu, J.S. Yang, X.Y. Chen, "Analysis of Cognitive Resource Management of Classroom Teaching Mode," Contemporary Educational Science, no. 3, pp. 65-72, 2021.

[4] L.P. Zeng, Z.P. Yang, E.H. Xie, "The application of the 'divided classroom' teaching mode in the teaching practice of 'management psychology'," Educational Theory and Practice, no. 27, pp. 52-54, 2018 .

[5] H.J. Zhang, C.S. Wang, "Research on the Development Path of High Quality of Financial and Economic Textbooks in Colleges and Universities from the Perspective of Curriculum Ideological and Political Education," China Publishing, no. 9. pp. 55-59, 2021.

[6] X.X. Zhang, "Separate Classroom: New Wisdom of Chinese Education,” Beijing: Science Press, 2016.

[7] H.Y. Wang, "Research on Integrating Ideological and Political Education into Applied Curriculum Teaching — Taking 'Tourism Public Relations' as an Example,” Journal of Kashgar University, no. 4, pp. $110-115,2020$

[8] H.Y. Li, H.X. Tian, L.W. Ma, H.Y. Zhang, N.N. Gao, "Research on the Application of Divided Classroom Teaching Mode in Geography Teaching in Senior High School," Education and Teaching Forum, no. 10, pp. 268-269, 2020.

[9] R.F. Chen, Z.C. Chen, "Research on the Application of New Media Attraction in Separate Classroom Teaching," School Party Building and Ideological Education, no. 18, pp 90-92, 2019. 